\title{
Labour migration: legal means of regulation in the context of contemporary challenges
}

\author{
Ludmila Vasilievna Andrichenko and Inna Vladimirovna Plyugina ${ }^{1}$ \\ Institute of Legislation and Comparative Law under the Government of the Russian Federation, \\ Center for Public Law Research, Moscow, Russia
}

\begin{abstract}
For a long time, the Russian Federation has been one of the world's leaders in terms of the number of international migrants, a significant proportion of which are labour migrants. This required the development of a legal framework that would make it possible, on the one hand, to ensure the security of the state and the host society, create conditions for a prompt and flexible response to the situation in the labour market, and, on the other hand, protect the rights and freedoms of foreign nationals working in Russia, and create an attractive migration climate. The article highlights the current developments in the statutory regulation of labour migration, the legal means used to respond to modern challenges and formulates the major problems facing government bodies. Purpose: on the basis of an analysis of the development of the migration legislation of the Russian Federation, to identify the features of the regulation of labour migration and determine the areas of modernisation of the legal framework in that field. Basic methods: formal-logical, system-structural, special-legal, comparative-legal; content analysis, etc. Results: by evaluating the dynamics of legal regulation of labour migration in the Russian Federation in recent decades, the following features can be distinguished: detailed and differentiated legal status of various categories of foreign nationals involved in labour activities in Russia; the focus of legislation on the use of flexible mechanisms for foreign labour intake, which presuppose taking into account professional qualities and the level of qualifications; increased role of supranational regulators in the legal regulation of migration relations (CIS, EAEU, etc.); introduction of the technological advance achievements into the public administration mechanism which made it possible to improve control measures and migration registration etc. The developed legal means for regulating migration processes need interval updating in order to ensure an adequate response to changes in political, social, economic and other conditions, effective impact on the migration situation by taking into account the purpose and intent of the state migration policy.
\end{abstract}

Keywords: labour migration, labour migrants, foreign nationals, labour activities, migration legislation

${ }^{1}$ Corresponding author: inna_wp@mail.ru 


\section{Introduction}

For several decades, Russia has been at the forefront of global migration processes; in 2020 it ranked fourth in the world in terms of the number of international migrants [1]. The COVID-19 pandemic situation and the associated restrictions had a direct impact on migration processes and reduced the Russian positive migration balance. In Quarter 1 of 2020 , it corresponded to the average level in recent years, but was $38 \%$ lower than in the same period of 2019 [2]; however, similar processes can be recorded in other countries, where the pandemic has also seriously disrupted all forms of human mobility including international migration. Although the influx of labour migrants has decreased due to the COVID-19 pandemic, the areas and composition of labour migration as a whole remain stable being shaped in the overwhelming majority of citizens of the Commonwealth of Independent States.

Foreign nationals constitute a significant component of the labour resources of economic sectors of a number of regions of the country (construction, agriculture, housing and communal services, the provision of transport services, etc.). This determines the intensive enhancement of the Russian regulatory framework in the field of migration in general and, above all, in the field of labour migration. As the law enforcement practice results show, the legislative measures adopted in recent years have generated a tangible positive effect, and the foundations of a balanced migration policy of the Russian Federation have been laid. As a result of regulatory changes, the state has received tools for more flexible regulation of migration processes including optimisation of many administrative procedures which has increased the predictability of migration flows; the effectiveness of measures of state control (supervision) and the provision of public services has increased; the public-private partnership possibilities in the implementation of programmes for adaptation and integration of migrants have been expanded. At the same time, updating the strategic goals and objectives of the state migration policy, the development in 2020 of a new concept of legal regulation of its key areas requires an additional scientific assessment of the existing legal tools used to regulate labour migration, substantiation of migration legislation development forecasts.

The research community has been strongly focused on issues of the legal regulation of labour migration; there are both comprehensive studies $[3,4]$ and those devoted to its individual aspects $[5,6]$; a significant number of works are focused on the study of those issues in the aspect of international law [7-9], although in general, the share of legal research is not dominant in the total array of works. Researchers critically assess the foreign labour intake mechanisms, the licensing procedures used to regulate labour migration, they are looking for an optimal balance of public and private interests.

It is noted that migration research, for a long time, has suffered from a divided approach based on a simplified opposition of forced and voluntary migration: "Research in sociology, anthropology and political science has discovered the inadequacy of this binary categorisation, given that the movement of people across borders is caused by a combination of many reasons, aspirations, motivations and factors that overlap and are not mutually exclusive" [7]. It is stated that it is difficult to talk about forced and voluntary migration as distinct categories as they probably exist rather on a continuum [10].

Migration issues are regulated by various branches of law including labour, administrative, civil ones, etc. When assessing the correlation of migration legislation with other branches and institutions, it is noted that in some countries, in practice, compliance with migration legislation is a priority, in particular, in relation to legislation in the area of work and employment [11]. 
A number of publications criticise the labour migration management paradigm, which assumes dependence on short-term economic needs and demand from local employers; justifies the feasibility of transition to a "hybrid system", according to which labour migrants are selected taking into account various criteria (language, age, previous experience in the country of destination, professional experience, etc.), and not only on the basis of their immediate needs of the employer [12].

An increase in the number of legal statuses of labour migrants, the emergence in this regard of various legal configurations, is recorded [13]. At the same time, some researchers point to the fact that the categories of migrants are artificial without often meeting the realities of life [14].

A promising area of research is the research into the limits of administrative discretion in the implementation of public administration in the field of labour migration. It is noted that law-making always implies forcing a general solution onto specific and often extremely differentiated individual situations [15]. It is emphasised that discretionary powers are a tool that ensures flexibility of migration regimes, which must stand the test of time and, in general, be able to meet the individual needs of both workers and employers; at the same time, it is emphasised that in the case when discretionary power holders are not held accountable, this power may become arbitrary [16].

\section{$2 \quad$ Materials and methods}

The issues raised were addressed with a systemic and structural analysis of Russian legislation and international regulatory documents, a critical study of the key outcomes of research and analysis related to the labour migration regulation. In the course of the research, the latest initiatives were taken into account involving the systematisation of migration laws and the modernisation of the overall model for regulating labour migration (this refers to the concept of the draft federal law "Conditions of Entry (Exit) and Stay (Residence) in the Russian Federation of Foreign Nationals and Stateless People"). The use of formal-logical and special-legal research methods contributed to ensuring consistency of conclusions and judgments, identifying the main trends in the development of labour migration legislation, assessing the existing tools used to achieve the goals and objectives of the state migration policy. Comparative legal and systemic and structural methods were used to determine possibilities for improving legal regulation in that area.

\section{$3 \quad$ Results}

1. Almost every recipient state has to resolve issues related to the protection of the national labour market and the prevention of illegal labour activities of foreign nationals.

To ensure the request of business entities to involve those particular foreign specialists that are in demand, foreign labour selection tools are used. Some states use a point system (for example, Canada, Australia), others, as the main means of state influence, use quota mechanisms that establish prohibitions and restrictions on engaging foreign nationals in certain areas or professions, etc.

The migration policy implemented by the Russian Federation pursues the regulation of the number of foreign workers involved, also based on the real situation and trends in the Russian labour market taking into account the needs of the economy and the citizens' interests. In this regard, the Russian Federation Government annually determines the general need for foreign workers arriving in the country with a visa including by priority 
professional qualification groups and taking into account the political, economic, social and demographic situation. In addition, the permissible share of foreign workers employed in various sectors of the economy by business entities operating in Russia is being changed. At the same time, the need for further differentiation of the conditions and procedure for involving foreign labour and expanding the practice of using selective mechanisms has become apparent for a long time.

The subsequent development of the national model for regulating labour migration can be seen in two possible areas, namely by improving the existing mechanisms and further differentiating the procedure for attracting foreign labour, or through a gradual transition to a point system, the feasibility of which is named by many researchers [17, 18]. At the same time, switching to a point-based system will require significant organisational and time costs, and will also entail a reform of the entire migration legislation and the existing institutional framework, since it will lead to the transfer to the state, that currently sets only general parameters, of the principal risks associated with assessing the level of professional qualifications from employers and customers of work (services).

2. In assessing the dynamics of legal regulation of labour migration in Russia, it is essential to state that the selective approach is increasingly being introduced into the general procedure for involving foreign labour, as manifested in stimulating the entry of certain categories of foreign nationals. The differentiation of the legal statuses of labour migrants is still in progress. In addition to such well-known categories as foreign workers, foreign nationals registered as individual entrepreneurs, foreign journalists, etc., new categories of labour migrants have appeared, in particular highly qualified specialists; qualified specialists; those invited to the Russian Federation as health workers, teaching staff or research employees and others. This "fragmentation" of legal statuses generally corresponds to the global trend, it makes it possible to more flexibly adjust the labour market in the state, solve issues associated with involving labour migrants for the needs of the economy and social sector. But if there are no any clear criteria for differentiation or any labour migration development areas determined in strategic planning documents of the Russian Federation, this approach leads to excessive complication and unjustified overloading of migration legislation.

In recent years, in the Russian legislation, a tendency to establish the specifics of carrying out labour activities by certain categories of foreign nationals in relation to specific territories has increasingly developed. Such special features are established in relation to foreign nationals working for residents of the free port of Vladivostok, in the Skolkovo innovation centre, the international medical cluster as well as the areas of advanced social and economic development, etc. At the same time, the regulation of such features is only growing, which increases the already accumulated array of reference provisions in the federal law "Legal Status of Foreign Citizens in the Russian Federation", although many such regimes for attracting foreign nationals duplicate each other. This requires the categorisation of legal regulation of the peculiarities of the labour activities of foreign nationals in special economic areas.

3. The experience of such regional interstate organisations as the Commonwealth of Independent States, and now the Eurasian Economic Union, testifies that the international legal regulation of labour migration today is becoming a unifying motive; it is aimed at solving the problems that are generated in connection with the intensification in that region of migration. In particular, the 2014 Eurasian Economic Union Treaty (EAEU) includes, among other forms of cooperation, the creation of a single labour market and migration management in the context of the free movement of goods, services, capital and workers in the common economic space. The adoption of the Treaty led to the allocation of a new 
category of migrants within the EAEU with an independent status, workers of the member states of the Union, who are granted the most favoured nation treatment as an element of the international legal cooperation mechanism. By establishing a simplified legal mode for the stay and employment of those persons, the EAEU member states create regional advantages in the global competitive environment for labour and thus isolate their regional labour market. All this proves that within the framework of the EAEU, being created is their own migration system characterised by stable migration flows that have developed thanks to strong historical, economic, cultural and other ties, as well as the presence of a special system of legal regulation of migration relations supported by the regulation of adjacent relations with the involvement of migrants (in the field of labour relations, social security, education, health care, etc.).

The weak side is that within the framework of the EAEU, a unified concept for managing migration processes, which would ensure effective interstate interaction between countries of destination and origin of migrants, has not yet been developed. There is also no interstate migration registration system in the EAEU, which would make it possible to carry out a comprehensive analysis of migration processes and ensure that they are managed. This indicates the presence of constraining factors for the development of the migration system within the EAEU in the interests of all its members. It is important to focus on one more factor, that hinders the formation of a full-fledged migration system within the EAEU, the EAEU migration policy is focused only on labour migration flows within the Union by regulating the status of only migrant workers who are citizens of the Union. It does not in any way affect the provisions of the national legislation addressed to migrants from other countries of the EAEU countries. On the one hand, this preserves the independence of these states in the choice of areas of their migration policy development, on the other hand, this does not ensure the unity of this migration system, restricts its integration properties.

4. In recent years, a noticeable emphasis in the regulation of migration relations in Russia, as in many other countries, has been on the determination of the IT procedure for the regulation of migration processes including labour migration. In particular, the point at issue is about the introduction of an electronic visa system, the use of digital and information technologies in order to simplify and optimise border control, the expansion of the use of modern biometric technologies for personal identification in order to increase the efficiency of state control (supervision) in the field of migration, ensure public safety and provide government services in the field of migration; improving administrative procedures in the field of migration through the introduction of electronic forms of interaction, as well as the creation, maintenance and development of state information systems etc. Nevertheless, the level of application of information technologies in order to identify foreign nationals when providing them with public services and exercising state control in the field of migration is still not high enough. Thus, experts note that it is necessary to further expand the use of up-to-date digital technologies in order to study, assess and predict changes in the migration situation; the use of biometric information in the implementation of state control (supervision) and the provision of public services in the field of migration [19].

In this regard, the initiative to issue ID-cards with personal data for foreign nationals staying in the Russian Federation for a long time, as well as for persons who have received the right to permanent residence, seems promising. It is assumed that such a card will be an identity document; it will be possible to issue it subject to fingerprint registration, photographing, medical examination, and confirmation of the existence of a voluntary medical insurance policy. 
5. The shift in the focus of the problems of regulatory policy in the field of labour migration to the socio-cultural sphere is due to the special importance of issues of the migrant socialisation. The influence of the sociocultural context is determined by the fact that migration policy has features that distinguish it from policy in other social areas. In this context, to a greater extent, certain sociocultural restrictions remain, which are due to the practice of interaction between the host population and immigrants. The "blurring" of the boundaries between the host community and migrants largely depends on the focus of the latter towards adaptation in the new social environment.

The provision of the legal basis for social and cultural adaptation and integration has not yet been completed, which is primarily due to the difficulties of the final choice of a common integration model. The creation of an integrated system for the provision of information services and legal support, including in the national languages of those states, from which the largest number of foreign nationals arrive, could contribute to solving the adaptation and integration problems. Measures aimed at adaptation and integration should be aimed not only at the labour migrants themselves but also their family members, who enter with them, and also involve working with the host society. In addition, it is necessary to more clearly delineate the powers of public authorities at various territorial levels.

\section{Discussion}

One of the debatable issues is the assessment of the possibility and feasibility of the transition to a point system. Despite the fact that this idea has a significant number of supporters and can be generally implemented in practice by taking into account the peculiarities of the modern legal system of the Russian Federation; nevertheless, it can hardly be taken unconditionally, given the significant number of foreign workers in Russia, as well as the visa-free border crossing regime established for many countries, as already indicated in earlier studies [20]. At the present stage, one of the regulatory options is the selective use of a point system to attract certain categories of foreign specialists, for example, those invited to implement large investment projects. This will make it possible to go through its approbation, identify the chances of further using it for the selection of specialists on a larger scale.

The employment differentiation trend by certain categories of foreign nationals recorded in recent decades will continue and will be associated with a layering of regulatory impact in the context of various legal frameworks applied in certain areas.

In the scientific literature, various migration systems are distinguished, among them North American, European, Asia-Pacific, Middle East, South American [21]; Russian scientist I.V. Ivakhnyuk substantiated that a Eurasian migration system has developed in the post-Soviet space, namely a group of post-Soviet countries linked by strong and numerous migration flows, which are caused by the interaction of a number of factors, i.e. historical, economic, political, demographic, socio-ethnic, geographical [22]. It can be argued that the migration sub-system is currently being generated within the EAEU.

The national integration model, which is not finalised in its final form, raises questions as to which social and cultural adaptation and integration measures should be applied to labour migrants, at whose expense they should be financed, over what period of time the use of them is relevant. The proposed combination of funding sources for such events should be supported; it can be carried out both at the expense of a foreign national himself/herself, the inviting party (in particular, the employer), civil society institutions, and at the expense of budgetary funds. An additional scientific assessment needs to determine 
the role of employers and/or work (service) customers during the adaptation and integration.

\section{Conclusion}

The identified trends in the development of migration legislation are due to the peculiarities of the political, social, economic, cultural and other conditions of the Russian Federation as a recipient state, in the territory of which there are a lot of foreign nationals. Currently, the Russian Federation has developed a toolkit that makes it possible to regulate labour migration and respond to factors affecting the labour market and migration situation; however, its regular updating takes place taking into account the adjustment of strategic goals and objectives, changes in the structure of migration flows, the emergence of new challenges and threats.

\section{References}

1. International Organization for Migration. World migration report 2020. Accessed on: October 2, 2021. [Online]. Available: https://www.un.org/sites/un2.un.org/files/wmr_2020.pdf

2. Y.F .Florinskaya, N.V. Mkrtchyan, Econ Devel Rus, 28(1), 50-54 (2021)

3. P.V. Pankin, Regulirovanie rynka truda s uchetom osobennostei trudovoi migratsii [Labor market regulation taking into account the specifics of labor migration]. (Yelets State University named after I.A. Bunin, Yelets, 2019)

4. A.V. Topilin, O.A. Parfentseva, Perspektivy trudovoi migratsii v Rossii: ot kolichestvennykh k kachestvennym parametram [Prospects for labor migration in Russia: from quantitative to qualitative parameters]. (MAKS Press, Moscow, 2008)

5. E.A. Malyshev, Regulirovanie vneshnei trudovoi migratsii administrativno-prinuditelnymi merami [Regulation of external labor migration by administrative and compulsory measures]. (INFRA-M, Moscow, 2016). https://doi.org/10.12737/18210

6. I.N. Scherer, Problemy molodezhnoi trudovoi migratsii Rossii [Problems of youth labor migration in Russia]. (Non-Governmental Educational Institution of Higher Professional Education, Volgograd, 2010)

7. V. Chetail, International Migration Law. (Oxford University Press, 2019)

8. D.K. Bekyashev, D.V. Ivanov, Mezhdunarodno-pravovoe regulirovanie vynuzhdennoi i trudovoi migratsii [International legal regulation of forced and labour migration]. (Prospect, Moscow, 2014)

9. S.E. Metelev, Mezhdunarodnaya trudovaya migratsiya v usloviyakh globalizatsii i nelegalnaya migratsiya $\mathrm{v}$ Rossii [International labor migration in the context of globalization and illegal migration in Russia]. (UNITI: Law and Law, Moscow, 2006)

10. E. Snel, Ö. Bilgili, R. Staring, J Ethnic Mig Stud, 47(14), 3209-3225 (2020). https://doi.org/10.1080/1369183X.2020.1804189

11. W. Palmer, A. Missbach, Third World Quart, 40(5), 908-925 (2019). https://doi.org/10.1080/01436597.2018.1522586

12. S. Sarolea, Legal migration in the "New Pact": modesty or unease in the Berlaymont? Accessed on: October 2, 2021. [Online]. Available: 
https://eumigrationlawblog.eu/legal-migration-in-the-new-pact-modesty-or-unease-in-t he-berlaymont/

13. J. Könönen, Work, Empl Soc, 33(5), 777-793 (2019).

https://doi.org/10.1177/0950017019835133

14. L. Sandoz, J Ethnic Mig Stud, 46(1), 222-241 (2020). https://doi.org/10.1080/1369183X.2018.1502657

15. M. Zamboni, The Theory Pract Leg, 7(2), 101-133 (2019). https://doi.org/10.1080/20508840.2020.1729599

16. T. De Lange, P. De Sena, The Theory Pract Leg, 7(2), 135-151 (2019). https://doi.org/10.1080/20508840.2020.1729559

17. A.G. Grishanova, E.S. Krasinets, Immig Law, 1, 26-30 (2014)

18. O.T. Suyunchaliyeva, Proc Acad Manag Ministry Int Aff Rus, 2(22), 123-125 (2012)

19. V.E. Vasiliev, K.V. Vlasova, Sci J "Epomen”, 44, 62-73 (2020)

20. L.V. Andrichenko, J Rus Law, 7, 5-16 (2011)

21. St. Castles, M.J. Miller, The Age of Migration: International Population Movements in the Modern World. (Palgrave Macmillan, New York, 2009)

22. I.V. Ivakhnyuk, RUDN Newsl, Int Rel Ser, 2, 21-28 (2008) 